\begin{tabular}{cc}
\hline Revista de & Journal of Integrated \\
GESTÃO COSTEIRA Integrada COSTALZONE MANAGEMENT \\
\hline
\end{tabular}

\title{
Cost-benefit analysis of coastal defenses on the Vagueira and Labrego beaches in North West Portugal
}

\author{
A. Maia ${ }^{\text {a }}$ C. Bernardes ${ }^{\circledR}$, b; M. Alves ${ }^{\mathrm{c}}$
}

\begin{abstract}
The Portuguese northwest coast has been suffering for decades from severe erosion and important geomorphological changes, particularly in sandy stretches. This process is related to a number changes which include: a reduction of the supply of sediments, an increase in the mean sea level, an increase of storm frequency and anthropogenic transformations. The Aveiro coastal stretch is morphologically characterized by a sandy barrier-lagoon system often referred to as Ria de Aveiro; the barrier has been submitted to a continuous narrowing and topographic reduction that together potentiate a significant retreat of the coastline, an erosion of the beaches, and over washing.

This paper analyses a coastal sector of approximately $3 \mathrm{~km}$ in length, between the Vagueira and Labrego beaches, located at the south of the jetties that protect the access to the Aveiro lagoon. The study includes the behaviour of the erosion in the last 52 years, the projection of the coastline for the year 2020 and a cost-benefit analysis (ACB) for two scenarios: the present, with the existent coastal defenses, and another one with the absence of defenses. We examined aerial photographs taken in different years in order to determine the different shoreline positions, historical trends and mean shoreline retreat. The analysis of the economic viability of the scenarios was carried out based on the calculation of present value (NPV). The historical (19582010) coastline retreat shows a value of about $-3.5 \mathrm{~m} /$ year, and if the hydrodynamic conditions remain identical to the present, by 2020 a loss of approximately 7 ha of territory is expected in semi-natural areas, assuming that the urban areas will continue to be protected. The cost-benefit analysis point out that investment in coastal defenses is not economically viable, particularly in hard defenses. This situation also occurs if nothing is to be done to preserve the natural and built areas. However, in the latter case the economic losses are smaller. Nonetheless, all scenarios and the impact of changes should be based not only on economic factors but also by taking into account the ecological and social importance of the coastal zones. Bearing in mind the present trend, and in order to continue to protect the urban front of Vagueira, the existing defenses will have to be maintained and reinforced, which will mean more investment in the near future.
\end{abstract}

Keywords: Ria de Aveiro, barrier, coastal defenses, coastal erosion, shoreline.

\section{Resumo}

\section{Análise de custo benefício de obras de defesa costeira nas praias da Vagueira e do Labrego}

A costa ocidental portuguesa e, em particular, a zona litoral de Aveiro tem sofrido nas últimas décadas profundas alterações morfológicas, devido à erosão persistente. Este processo está relacionado com o reduzido volume de sedimentos disponível neste segmento costeiro, a ação dos temporais, as ações antropogénicas e a subida do nível médio do mar. Neste contexto, a

\footnotetext{
(a) Corresponding author to whom correspondence should be addressed.

${ }^{\text {a }}$ Universidade de Aveiro, Departamento de Ambiente e Ordenamento, 3810-193 Aveiro, Portugal. e-mail: $<$ maiaandreia@ua.pt $>$.

${ }^{\mathrm{b}}$ Universidade de Aveiro, Departamento de Geociências e CESAM, , 3810-193 Aveiro, Portugal. e-mail: <cbernardes@ua.pt>

${ }^{\mathrm{c}}$ Universidade de Aveiro, Departamento de Economia, Gestão e Engenharia Industrial e GOVCOPP, 3810-193 Aveiro, Portugal. e-mail: $<$ mrobaina@ua.pt>
}

* Submission: 7 JUN 2014; Peer review: 6 JUL 2014; Revised: 15 OCT 2014; Accepted: 22 OCT 2013; Available on-line: 23 OCT 2014
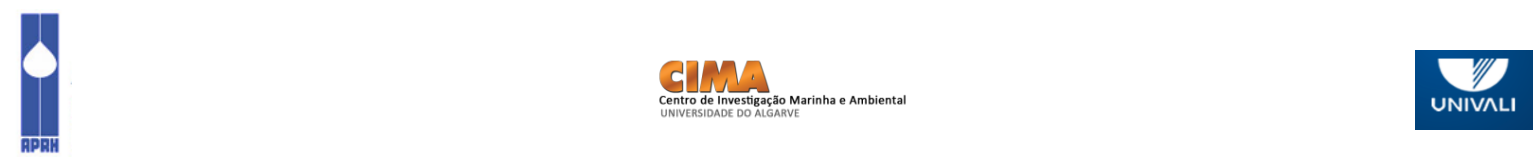
barreira arenosa, que define a laguna de Aveiro, tem experimentado um contínuo estreitamento e rebaixamento topográfico que, em conjunto, potenciam um significativo recuo da linha de costa, erosão das praias e galgamentos oceânicos.

No presente trabalho é analisado o setor costeiro entre as praias da Vagueira e do Labrego, localizado a sul dos molhes que protegem o canal de acesso à laguna de Aveiro. O estudo incluiu o estudo do comportamento da linha de costa, nos últimos 52 anos, a sua projeção para o ano de 2020, e uma Análise Custo-Benefício (ACB) para duas situações, a existente na atualidade, com obras de defesa costeira e, outra, admitindo a ausência de defesa. Neste contexto, foram examinadas fotografias aéreas de diferentes anos com vista à delimitação das linhas de costa e calculado o recuo médio; a análise da viabilidade económica dos cenários foi realizada a partir do cálculo do Valor Actual Líquido (VAL). O recuo médio da linha de costa foi de -3,5m/ano, com particular expressão nas áreas não protegidas, e se as condições hidrodinâmicas permanecerem idênticas às atuais, até 2020 é esperado um recuo de cerca de $30 \mathrm{~m}$ a que corresponde uma perda de 7 ha de área semi-natural da barreira, admitindo que as áreas edificadas continuarão a ser protegidas. A Análise Custo-Benefício mostra que o investimento em obras de defesa, em particular as de natureza pesada, não é economicamente viável. Situação que também se verifica se nada for feito para preservar o património natural e edificado. No entanto, o cenário sem obras de proteção acarreta menores prejuízos económicos. Convém, contudo, não esquecer que qualquer cenário deve considerar não só fatores económicos mas, também, a importância ecológica e social das zonas afetadas. Tomando em consideração a actual tendência e de modo a continuar a proteger a frente urbana da Vagueira, as obras de defesa existentes terão que ser mantidas e reforçadas o que implicará maior investimento num futuro próximo.

Palavras-chave: Ria de Aveiro, barreira, defesas costeiras, erosão costeira, linha de costa.

\section{Introduction}

The Portuguese coast, and in particular the Aveiro littoral zone, has been suffering for decades from strong erosion and coastline retreat. This process, induced by human actions that change the coastal dynamics, is a challenge for planning and coastal zone management and for the need to minimize impacts, whether through protective measures or loss of territory, natural and urban, as well as social and economic implications. Coastal defense work involves high costs, and it is therefore necessary to assess the economic viability of protective measures that impact at both a local and regional level.

The coastal zone of Aveiro is the most problematic of the north central region of Portugal, in terms of vulnerability and risk. This situation results from the geomorphologic features and the oceanographic context: a wide area with a pronounced topographic uniformity, exposed to wind action and to a strong maritime climate. The most important morphological element is the presence of a sandy barrier with a variable width. For decades, the barrier has presented transgressive characteristics, e.g., the rate of accumulation of sediment is less than the carrying capacity, so the coastline has been suffering a significant migration towards the land, induced by reduced sediment supply and washover processes. Similar situations observed in other systems are attributed to a rising mean sea level, a decrease in sediment delivery to the coast, anthropogenic influence and, in some cases, changes in the storm regime (Pethick 2001; Zhang et al. 2004).

The reduced sediment supply in coastal transport that affects the north and central Portuguese coast is referred to by several authors. The problem has been gathering over the last two decades, due to the changes in the northern rivers basins, particularly the Douro River because of its importance in sedimentary supply, and defense works carried out along the coast which retain a significant volume of sediment. Due to the problems that affect the Aveiro area, several authors have dedicated studies to the erosion and coastal defense (Dias et al, 1994; Boto et al, 1997; Taborda et al., 2005; Santos, 2008; Coelho et al, 2009;. Maia, 2012, among others), as well as issues related to the cost-.benefit of coastal protection investment (Alves et al, 2009; Roebeling et al, 2011; Roebeling et al, 2013).

The objective of this paper is to evaluate the behavior of the shoreline in the last 52 years, in the sector between the beaches of Vagueira and Labrego, and to evaluate the cost-benefit, and the impact of, coastal protection options (including groins, seawalls and also designated revetments) at local level.

\section{Study area}

The study area is located in the south of the Aveiro lagoon entrance (tidal channel), usually designated by Ria de Aveiro (Figure 1). The man-made tidal channel is sheltered by two large jetties which have undergone successive extensions, in particular the north jetty; these structures are part of a set of hard coastal defenses extending to the south.

This coastal stretch is morphologically characterized by a sandy barrier extending NNE-SSW that has been subjected to critical coastal erosion during the last few decades. The sector considered, the beaches from Vagueira to Labrego, with a length of approximately $3 \mathrm{~km}$, is backed by a degraded foredune ridge. The foredune shows dune morphologies poorly defined and partially destroyed by human occupation or erosive processes, and was replaced by sand dykes (Figure 1). The 


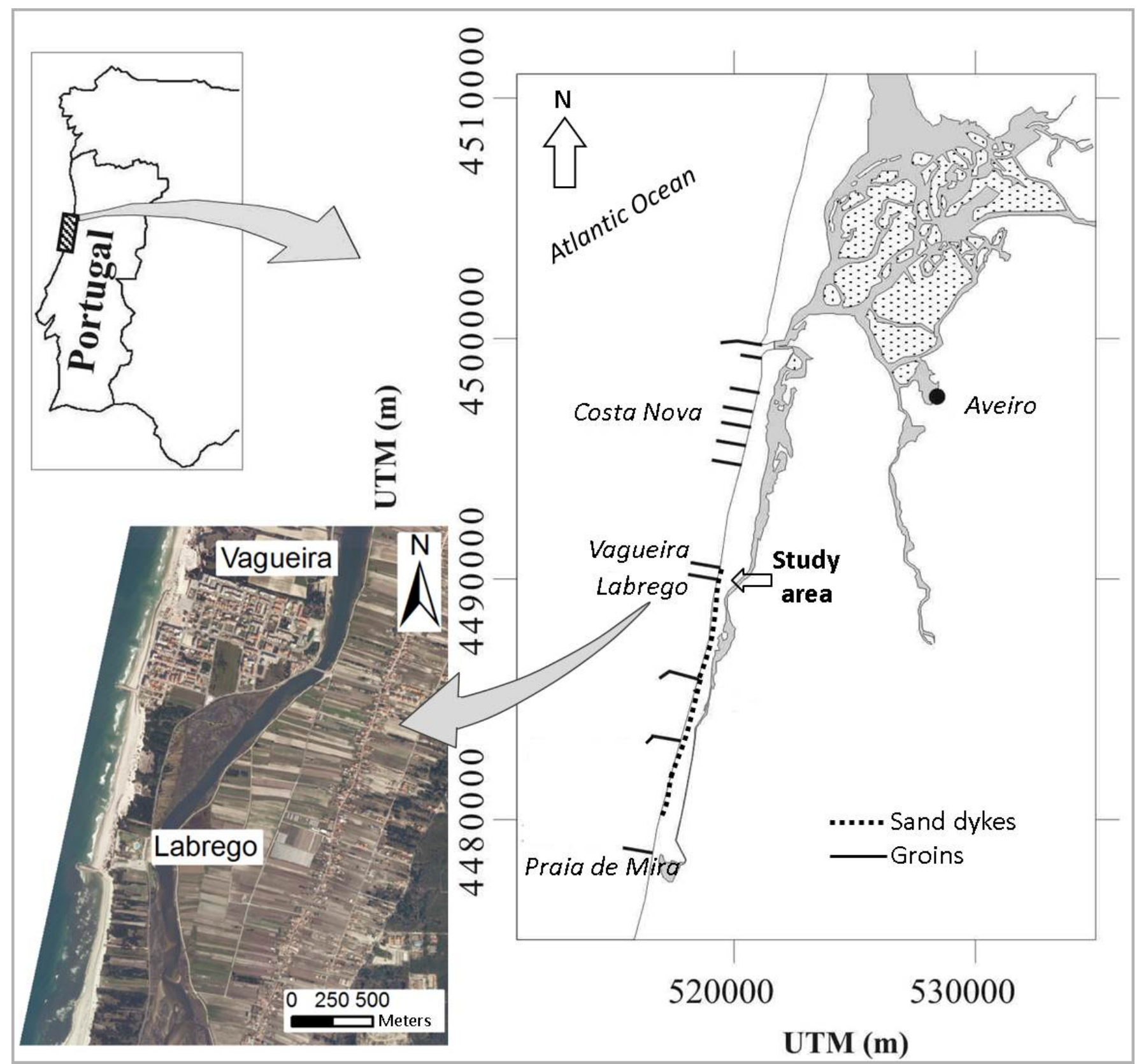

Figure 1 - Location of the study area.

Figura 1 - Localização da área de estudo.

dykes are man-made structures resulting from the settlement of sand from other places or sources, and play a protective role after the erosion of natural defenses.

The sandy barrier also individualizes two morphodynamic domains: an internal area, protected from direct action of marine processes which integrate the lagoon and the associated tidal flat, sometimes lower than the mean sea level, and an external domain, exposed to the ocean processes, that comprises the beach and the foredune or sandy dykes.

The whole area is characterized by high-energy wave conditions. Significant waves are smaller during summer (offshore significant wave heights of 1 to $3 \mathrm{~m}$ and wave periods of 11 to $13 \mathrm{~s}$ ) and larger during winter storms (significant wave heights often exceed $7 \mathrm{~m}$ and wave periods of $13 \mathrm{~s}$ ), particularly between October and March, with storms of greater intensity from the southwest (Costa, 1994). The mean wave direction is from NW and induces an important littoral drift from north to south. The semidiurnal mesotidal regime in the region presents a maximum tidal range of $3.2 \mathrm{~m}$ and a minimum tidal range of $0.9 \mathrm{~m}$; extreme water level fluctuations induced by storm surges usually exceed $40 \mathrm{~cm}$ (Gama et al., 1994).

The problems associated with beach erosion, washover and coastline retreat, result in a significant reduction in the mean width of the barrier, in particular, in the southern area of the entrance to the Aveiro lagoon be- 
tween Barra and Praia de Mira (Bernardes \& Baptista, 2011). As a result, episodes of over washing are sometimes accompanied by the opening of a temporary channel between the sea and the lagoon (Mira channel), as observed in 2001 and 2011, which destabilizes social and economic activity.

Vagueira is a very popular beach during the summer, particularly as the urban population has increased signifi cantly in recent years. Currently, the urban front is about $650 \mathrm{~m}$ long and is sheltered by a seawall, a longitudinal and adherent structure built in 1978. In 1979 this protection was reinforced and was accomplished by the construction of a groin in the southern area (Figures 1 and 2). These coastal protection measures have been subject to frequent maintenance interventions.

The Labrego beach, located about $1 \mathrm{~km}$ south of $\mathrm{Va}$ gueira, has a groin which was built between 1998 and
2002. The infrastructure, used seasonally, comprises: a water fun park, a bungalow park and some beach facilities (Figures 1 and 2). The sandy dykes are present at the south of the Vagueira and Labrego groins; downdrift the groin and dyke have been reconstructed and reinforced several times as a result of critical erosion during winter storms. The last major reconstruction work took place in 2011 following episodes of over washing and the opening of a temporary tidal channel; in February 2014, the sandy dyke was reinforced after severe storms.

\section{Materials and methods}

\subsection{Definition and calculation of shoreline retreat}

The analysis of aerial photography, at scales $1 / 25.000$ and $1 / 28.000$, was the basis for shoreline definition covering different years $(1958,1970,1998,2002$ and 2010),

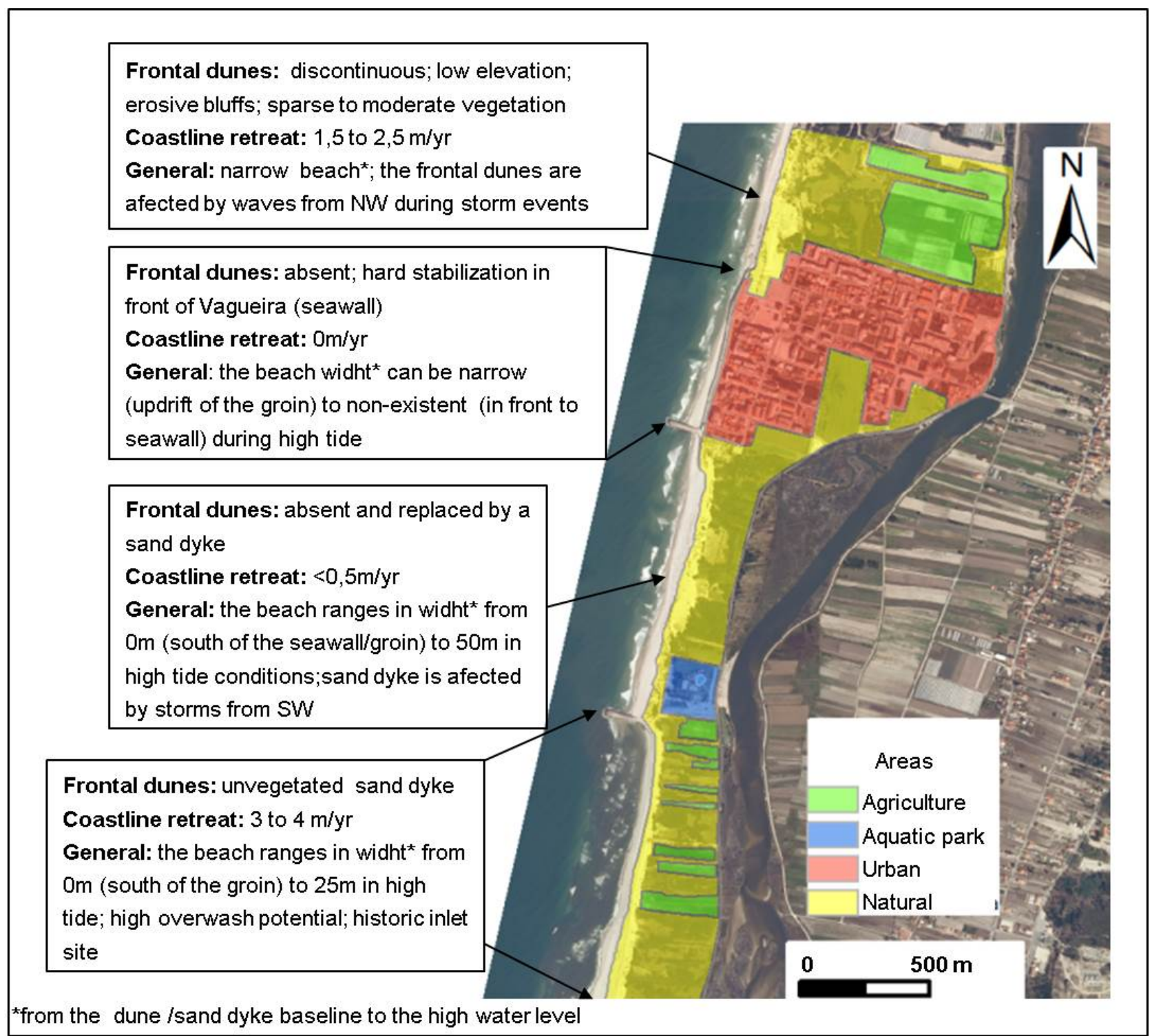

Figure 2. Land cover of study area.

Figura 2. Tipo de ocupação do solo na área de estudo. 
supported by a geographic information system (ArcGIS). Due to the variety of situations, the coastline reference was defined from

i) dune base when present,

ii) erosion escarpment carved on dune,

iii) base of sandy dyke when it replaces the frontal dune,

iv) base of longitudinal structure (fixed coastline).

For the years 2002 and 2010 the beach width, with potential use in the summer, was determined as the distance from coastline reference to the seaward limit of the subaerial beach in low water spring tides. An update of the built areas was also performed in Vagueira.

The rates of shoreline migration were calculated using the extension digital shoreline analysis system (DSAS). This data was the basis for the projection of the coastline for the years 2015 and 2020, according to that proposed by Ferreira et al. (2006). The projection took into account only the evolution trend of the shoreline and not any other factor, climatic, morphological change or anthropogenic action that modified the sediment dynamics in the study area. The shoreline position was calculated using the formula $S_{a}=S_{0}+S E R x a$, where $a$ is the time horizon to be analyzed; $S_{a}$ is the shoreline position after $a$ year's; $S_{0}$ is the position of the baseline considered (in this study is 2010); SER corresponds to the erosion rate.

\subsection{Cost-benefit analysis}

The cost-benefit analysis (CBA) has been realized in order to evaluate the costs and the benefits in the presence (with protection) and absence (no protection) of coastal defense works.

In the case of the presence of coastal defense, were calculated: i) the costs of construction and maintenance; ii) the costs associated if the defenses were replaced, called opportunity cost, in particular the longitudinal revetment of Vagueira; iii) potential loss due to the presence of structures such as groins that accentuate erosion downdrift of the same area.

The benefits arising from the protection calculated were: the protected area (not lost) due to the presence of the works and the increase of the beach width near the groins.

In the case of the absence of defense works, the costs of area potentially lost due to coastal erosion were estimated; the economic estimative, include natural areas of beach, dunes, inland adjacent zones, and urban areas based on the property value of homes. The benefit was calculated taking into account that any area lost due to the presence of hard coastal protection, including areas down-drift the groins.

In the study, the devaluation of the urban area situated in areas with risk of coastal erosion are not considered, since the houses in the water front are essentially seasonal residences and the factor of choice in the summer period is the proximity to the beach, as well as the socio-economic component and touristic activities that may be affected in the near future.

The costs and benefits calculated in the CBA were based on the values associated with the defense works and the natural and urban areas, estimated by Roebeling et al. (2011) and updated for the year 2012, using the inflation GDP deflator (World Bank, s/d) (Table 1).

Table 1 - Values associated with costs and benefits of coastal defenses.

Tabela 1 - Valor associado aos custos e beneficios da protecção costeira.

\begin{tabular}{|c|c|c|}
\hline \multirow[b]{2}{*}{ Seawall ${ }^{\mathrm{a}}$} & Investment coasts & $10.137 € / \mathrm{m}$ \\
\hline & $\begin{array}{l}\text { Maintenance costs } \\
\quad(\mathrm{yr} 3,6 \ldots)\end{array}$ & $2.282 € / \mathrm{m}$ \\
\hline \multirow[b]{2}{*}{ Groins $^{\text {a }}$} & Investment coasts & $12.671 € / \mathrm{m}$ \\
\hline & $\begin{array}{l}\text { Maintenance costs } \\
\quad(\mathrm{yr} 3,6 \ldots)\end{array}$ & $2.534 € / \mathrm{m}$ \\
\hline \multirow[b]{2}{*}{ Sand dyke ${ }^{b}$} & Investment coasts & $867 € / \mathrm{m}$ \\
\hline & $\begin{array}{c}\text { Maintenance costs } \\
(\mathrm{yr} 3,6 \ldots)\end{array}$ & $867 € / \mathrm{m}$ \\
\hline \multirow{2}{*}{$\begin{array}{l}\text { Protected area } \\
\text { and lost area }\end{array}$} & $\begin{array}{c}\text { Natural } \\
\text { (beach and dune) }\end{array}$ & $28.781 € / \mathrm{m}$ \\
\hline & Urban $^{\mathrm{d}}$ & $623.048 € / \mathrm{m}$ \\
\hline
\end{tabular}

${ }^{a}$ Coastal defense intervention investment and maintenance costs in central Portugal (Roebellinget al., 2011)

${ }^{\mathrm{b}}$ Sand dyke investment and maintenance costs in southern Vagueira beach

${ }^{c}$ Coastal ecosystem values (Roebellinget al., 2011)

${ }^{\mathrm{d}}$ From Almeida (2011)

The economic viability of the scenarios was carried out from the equation proposed by Roebeling et al. (2011), which allowed us to calculate the Net Present Value (NPV).

$$
\sum_{t=0}^{n} \frac{B_{t}}{(1+r)^{t}}-\sum_{t=0}^{n} \frac{C_{t}}{(1+r)^{t}}>0
$$

where $t=0, n$ ( $n$ is the number of years considered: 0 is the first year, in this case 1978, and $n=2020$ ); $r=$ time discount rate in the year $t ; B t=$ total benefits expected in the year $t ; C t=$ total costs, expected in year $t$.

The time discount rate allowed converting the costs and benefits to present values that will be compared. The decreasing discount rate was used because it permits a better valorization of the costs and benefits over major time periods (HM Treasury, 2003).

The benefits of coastal defense works are not immediate but only evident in the medium and long term; for that reason a higher value is given to the benefits in the CBA when compared with a constant discount rate. In 


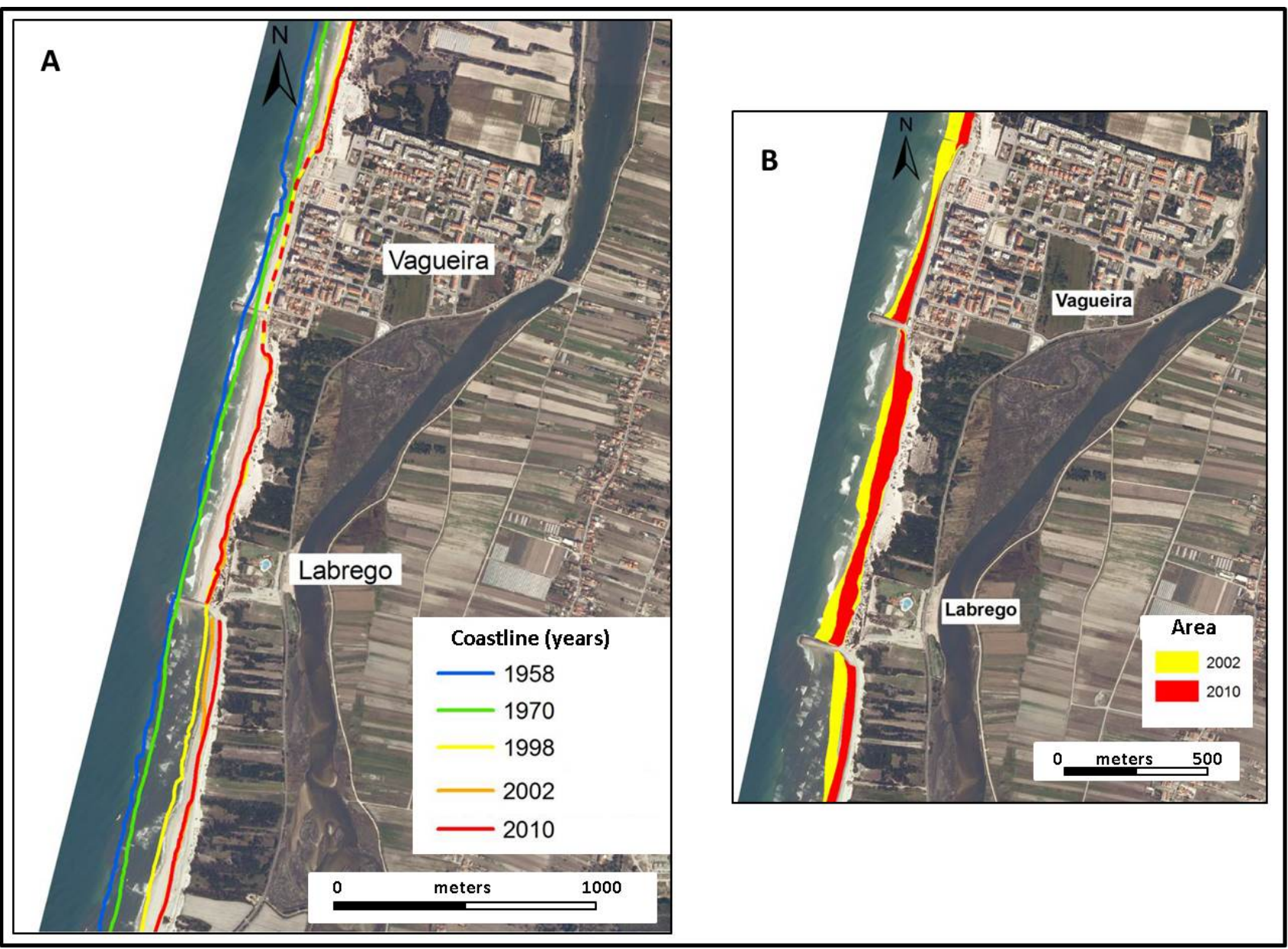

Figure 3 - A. Evolution of shoreline between 1958 and 2010. B. Beach area in 2002 and 2010 in low tide level (Maia, 2012).

Figura 3 - A. Evolução da linha de costa entre 1958 a 2010. B. Área útil de praia em 2002 e 2010 em situação de baixa-mar, 2002 e 2010 (Maia, 2012).

this case, for the period of 30 years, from 1970 to 2000 , a discount rate of $3.5 \%$ was considered, and for the following period, from 2001 to 2020 , a rate of about $3 \%$.

\section{Results and discussion}

\subsection{Evolution of the shoreline}

The shoreline evolution for the period between 1958 and 2010 shows a general retreat, which was accentuated after the coastal protection works, which were started in 1978 (Figure 3.A).

The aerial photography of 1958 did not reveal situations of erosion in the Vagueira zone: the beaches were wide and the foredune well developed. However, in 1970 and without defense structures, some erosion in the foredune system was recognised, which may return the effects of the interventions in the north region, specifically in Costa Nova and nearby the main entrance to the Aveiro lagoon (Figures 1 and 3).

Constructions of coastal defense structures in Vagueira (APA, 2012) began at the end of the 70s and were accompanied almost simultaneously by an increase of ur ban occupation; the density of built area has increased significantly over the past few decades (Figure 4).

In 1998 the coastline, influenced by the adherent structures, showed a "fixed" position along the longitudinal seawall and a rotation tendency immediately downdrift of the groins, accompanied by an important coastline retreat. From 1998 to 2002 the shoreline remained relatively stable, except to the south of the Labrego groin, with an increasing erosion area (Figure 3.A).

Between 2002 and 2010, the position of the shoreline remained constant between the Vagueira and Labrego beaches, recording some retreat to the south of the Labrego groin (Figure 3.A).

The subaerial beach area between the mean low-water level and the base of the seawall or dune/sand dyke, has been being reduced since 2002 (Figure 3.B). Until 2010 there was a mean decrease of about 8,8 ha of total surface area (approximately 1 ha/year, from 2002 to 2010), which was felt along the beach, including in the area $200 \mathrm{~m}$ immediately updrift of the groins. This trend had already been observed in 2010 and associated with the 


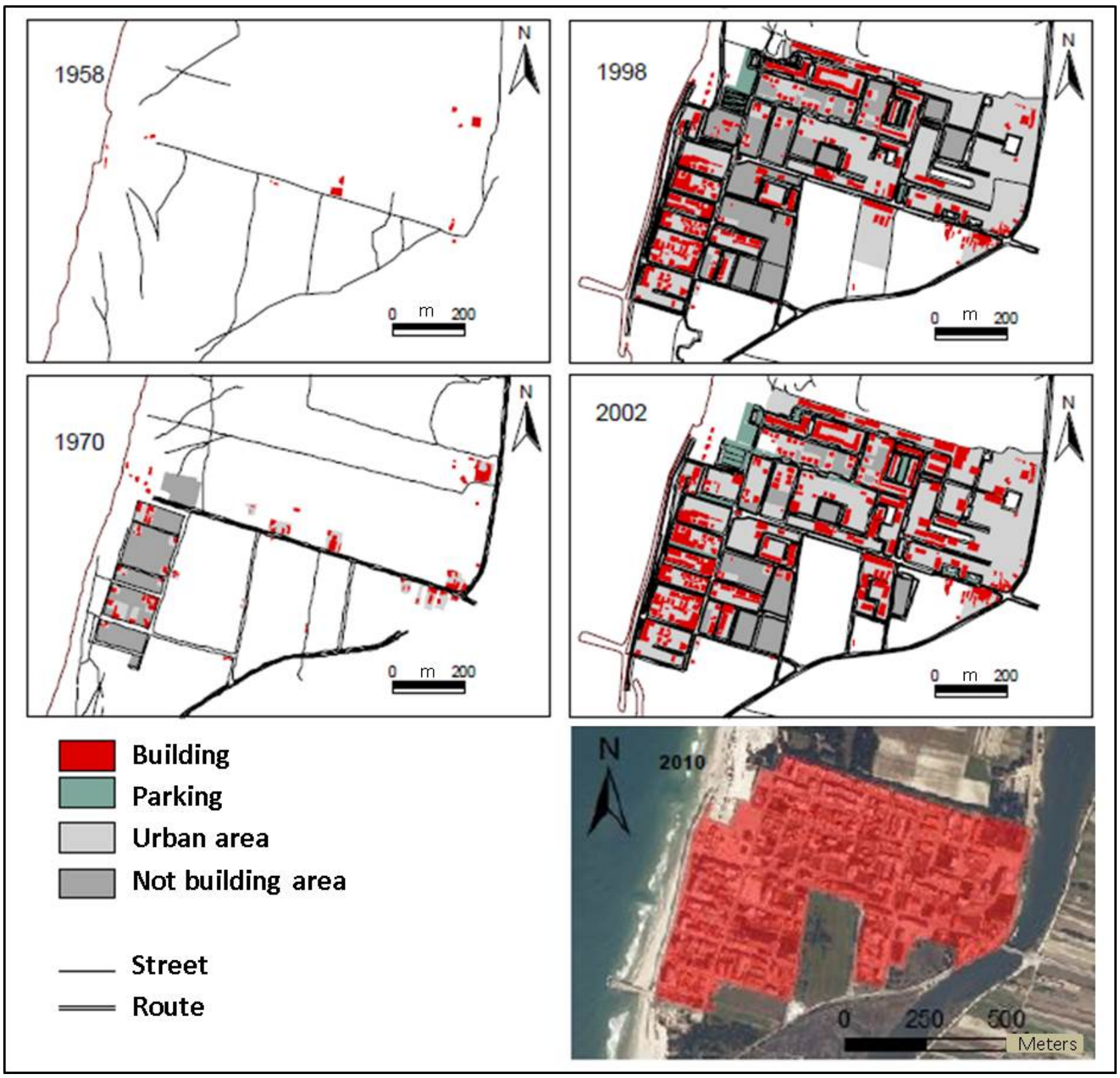

Figure 4 - Evolution of Vagueira urban area, between 1958 and 2010 (Maia, 2012).

Figura 4 - Evolução da área urbana da Vagueira entre 1958 e 2010 (Maia, 2012).

decrease of the average width of the sand barrier (beach and dune system) with a value of about $250 \mathrm{~m}$ in the Vagueira area (Bernardes \& Baptista, 2011).

The coastline between 1958 and 2010 shows an average retreat of $-3,5 \mathrm{~m} /$ year, which reflects the trend of the entire littoral sector. Before the construction of coastal defenses a mean value of $-3,2 \mathrm{~m} /$ year had been recorded, and after building this value reached $2,5 \mathrm{~m} /$ year (Maia, 2012). The decrease in the shoreline retreat rates that was not verified to the north or south of the Vagueira stretch was due to the coastline fixation in the urban front, balancing the retreat recorded before, and to the accretion which became to occur updrift of the Labrego groin (Figure 5). Although the retreat has diminished in relative terms, there was an increase of erosion downdrift of the groins that caused the partial destruction of the frontal dunes and their reinforcement or total replacement by sandy dykes.

The shoreline projection for the years 2015 and 2020 was performed by taking into account the present situation and a hypothetical scenario without protection of either fixed (adherent defenses) or dynamic (sandy dykes and beach nourishment). The results show, as expected, that the coastline retreat in the Vagueira waterfront and updrift of the Labrego groin would be greater without defense structures, while in areas protected by groins the retreat would be less significant in the absence of the protective structures.

For the period 2010-2015 it is estimated that the present coastal defenses avoid an erosion of 13,5 ha of total area (9 ha of dunes and sandy dyke, 4,5 ha of urban area and 6 ha of area not protected). By 2020, it is 


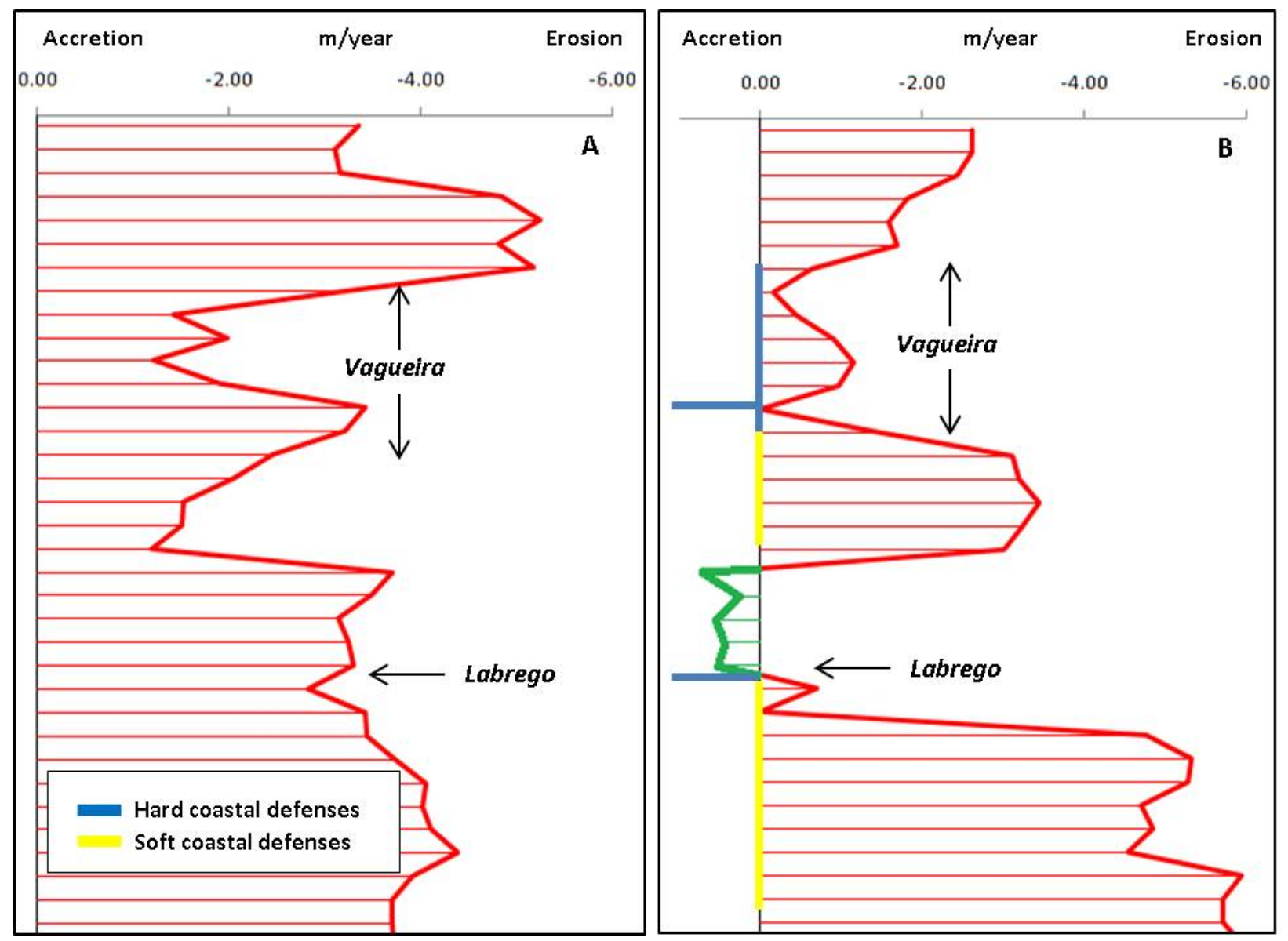

Figure 5 - Erosion and accretion rates of shoreline (in m/year) in Vagueira and Labrego. A- Before the implementation of the coastal defenses. B- After the implementation of the coastal defenses (Maia, 2012).

Figura 5 - Taxas de erosão e acreção da linha de costa (m/ano) na Vagueira e na praia do Labrego. A-Antes da construção das obras. B-Após a construção das obras (Maia, 2012).
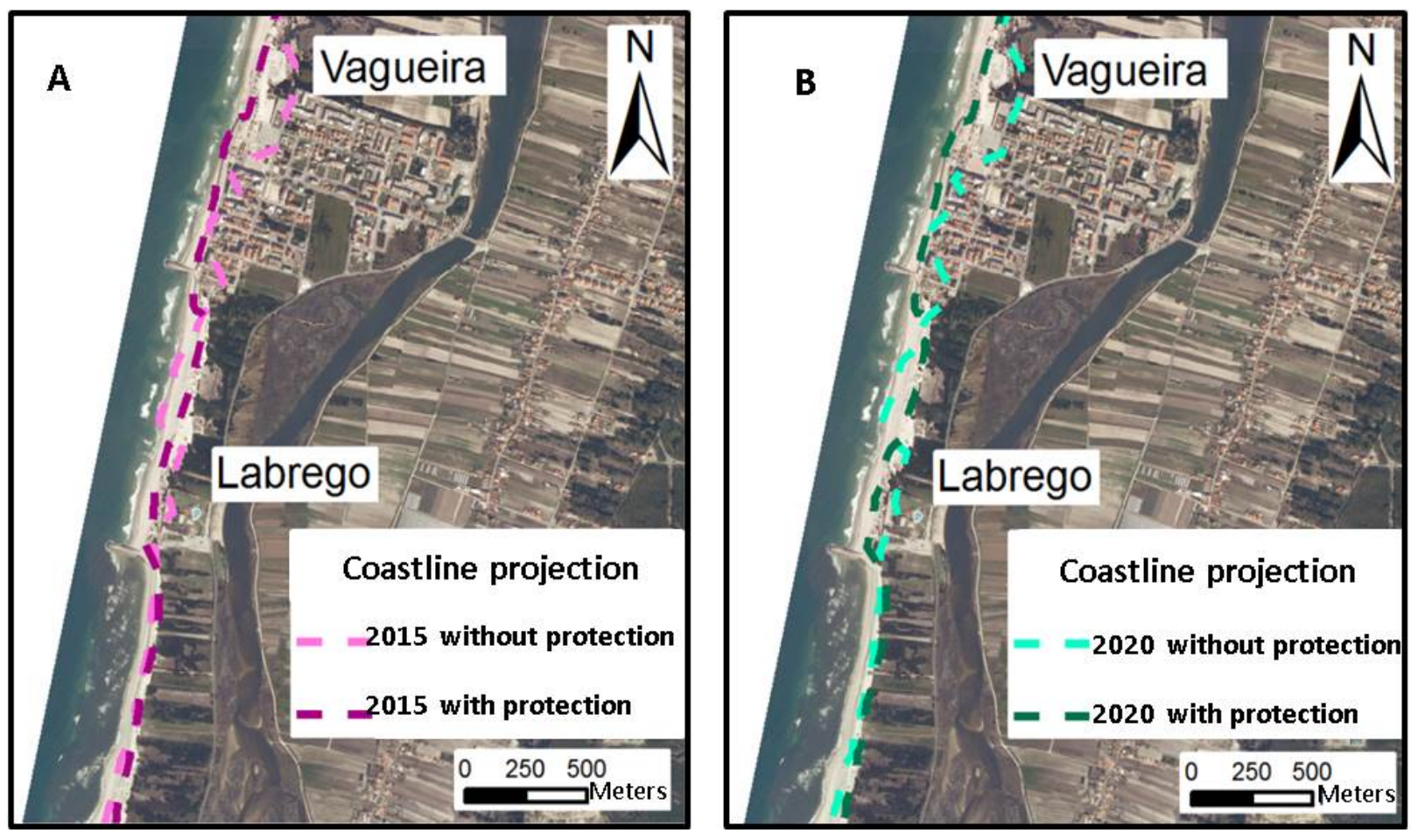

Figure 6 - Projection of shoreline position for the years 2015 (A) and 2020 (B) (Maia, 2012).

Figura 6 - Projecção da linha de costa. A- 2015; B- 2020 (Maia, 2012). 
estimated that 7 ha will be eroded and 16 ha protected $(10,4$ ha of semi-natural area and 5,6 ha of urban area) (Figure 6).

\subsection{Cost-benefit analysis (CBA)}

In Vagueira, the results of ACB show for the situations with and without protection a negative NPV in the periods considered, indicating the unviability of the defense structures, taking into account only economic reasons (Table 2). Coastal protection involves high construction costs and also ongoing maintenance costs; the total costs outweigh the benefits provided to natural and urban areas (Table 1). For a hypothetical scenario without the defense works the VAL, although negative, is much lower even in the near future.

For the Labrego beach, the results of the CBA are similar to the situation in Vagueira. In both scenarios, with and without protection, the NPV is always negative, though lower costs are observed in a scenario of no protection (Table 3 ).

In the period 1998-2002, the benefits created by the groins were negative because this period coincided with the construction of the structure and its effects still have not yet been felt. For a longer period of analysis, the costs are greater than the benefits. In the period 19982010, the costs associated with the eroded area have increased which has caused a drastic increase in NPV.

The projections for 2015 and 2020, both for Vagueira and Labrego as well as the costs associated with the presence of structures, largely penalize the benefits; amounts relating to the loss of territory without protection are considerably lower, which raises some questions regarding the value assigned to the intrinsic value of ecosystem components.

\section{Conclusions}

The coastal defenses on the Vagueira and Labrego beaches have contributed to the mitigation of negative impacts caused by coastal erosion. In Vagueira, the shoreline has remained "fixed" since the early 80 s, due to the construction of the seawall; the beach will still benefit from the presence of the groin in the southern zone, however, in the urban front the subaerial beach area has been decreasing, and even nonexistent during high tide conditions. Despite the reinforcement of the seawall, under storm conditions the structure suffers frequent overtopping and both the areas to north and south are seriously affected by breaking wave and wave set up, necessitating emergency repair work (Figure 2).

The projection of the shoreline based on the most simplistic formulation, that excluded the increase of mean sea level, the impact of storms and the storm surge, the morphodynamic characteristics of the coastal stretch, or anthropogenic intervention, shows that the short term coastal retreat, in the absence of defense works, would be significant and can induce considerable damage. The position of the projected coastline for 2015 has already been reached and slightly exceeded in February 2014;

Table 2 - Cost-benefit analysis of the coastal defense in Vagueira.

Tabela 2 - Análise Custo-Benefício (ACB) das obras da Vagueira.

\begin{tabular}{|c|c|c|c|c|c|c|}
\multicolumn{2}{c|}{ VAGUEIRA } & $\mathbf{1 9 7 0 - 1 9 9 8}$ & $\mathbf{1 9 7 0 - 2 0 0 2}$ & $\mathbf{1 9 7 0 - 2 0 1 0}$ & $\mathbf{1 9 7 0 - 2 0 1 5}$ & $\mathbf{1 9 7 0 - 2 0 2 0}$ \\
\hline \multirow{3}{*}{$\begin{array}{c}\text { Without } \\
\text { protection }\end{array}$} & Total benefits $(€)$ & 46.749 & 41.773 & 29.509 & 36.577 & 43.357 \\
\cline { 2 - 7 } & Total costs $(€)$ & 1.411 .039 & 1.728 .628 & 2.444 .657 & 3.091 .508 & 3.697 .639 \\
\cline { 2 - 7 } & Net Present Value $(€)$ & $\mathbf{- 1 . 3 6 4 . 2 9 1}$ & $\mathbf{- 1 . 6 8 6 . 8 5 5}$ & $\mathbf{- 2 . 4 1 5 . 1 4 8}$ & $\mathbf{- 3 . 0 5 4 . 9 3 2}$ & $\mathbf{- 3 . 6 5 4 . 2 8 2}$ \\
\hline \multirow{3}{*}{$\begin{array}{c}\text { With } \\
\text { protection }\end{array}$} & Total benefits $(€)$ & 1.308 .717 & 1.605 .988 & 2.368 .138 & 2.903 .120 & 3.482 .609 \\
\cline { 2 - 7 } & Total costs $(€)$ & 14.561 .992 & 16.155 .154 & 18.086 .819 & 19.388 .210 & 20.271 .067 \\
\cline { 2 - 7 } & Net Present Value $(€)$ & $\mathbf{- 1 3 . 2 5 3 . 2 7 4}$ & $\mathbf{- 1 4 . 5 4 9 . 1 6 6}$ & $\mathbf{- 1 5 . 7 1 8 . 6 8 1}$ & $\mathbf{- 1 6 . 4 8 5 . 0 8 9}$ & $\mathbf{- 1 6 . 7 8 8 . 4 5 8}$ \\
\hline
\end{tabular}

Table 3 - Cost-benefit analysis of the coastal defense in Labrego beach.

Tabela 3 - Análise Custo-Beneficio (ACB) das obras da praia do Labrego.

\begin{tabular}{|c|c|c|c|c|c|}
\multicolumn{2}{c|}{ LABREGO } & $\mathbf{1 9 9 8 - 2 0 0 2}$ & $\mathbf{1 9 9 8 - 2 0 1 0}$ & $\mathbf{1 9 9 8 - 2 0 1 5}$ & $\mathbf{1 9 9 8 - 2 0 2 0}$ \\
\hline \multirow{3}{*}{$\begin{array}{c}\text { Without } \\
\text { protection }\end{array}$} & Total benefits $(€)$ & 136.086 & 136.086 & 187.215 & 242.626 \\
\cline { 2 - 6 } & Total costs $(€)$ & 82.057 & 196.547 & 289.304 & 450.447 \\
\cline { 2 - 6 } & Net Present Value $(€)$ & $\mathbf{5 4 . 0 2 9}$ & $\mathbf{- 6 0 . 4 6 1}$ & $\mathbf{- 1 0 2 . 0 8 9}$ & $\mathbf{- 2 0 7 . 8 2 1}$ \\
\hline \multirow{4}{*}{$\begin{array}{c}\text { With } \\
\text { protection }\end{array}$} & Total benefits $(€)$ & 0 & 4.110 & 53.511 & 107.468 \\
\cline { 2 - 6 } & Total costs $(€)$ & 3.050 .179 & 6.851 .946 & 8.526 .151 & 10.360 .651 \\
\cline { 2 - 6 } & Net Present Value $(€)$ & $\mathbf{- 3 . 0 5 0 . 1 7 9}$ & $\mathbf{- 6 . 8 4 7 . 8 3 7}$ & $\mathbf{- 8 . 4 7 2 . 6 4 0}$ & $\mathbf{- 1 0 . 2 5 3 . 1 8 3}$ \\
\hline
\end{tabular}


this situation took place as a consequence of the highly energetic and persistent storms that affected the Portuguese coast last winter. In the study area, it was necessary to proceed with the partial nourishment of the beach in the area immediately north of the Vagueira seawall and the reinforcement of sandy dykes (Fig. 2). Emergency action of this type has been relatively effective in maintaining shoreline position and preventing coastline erosion trends. The CBA shows that coastal defenses on the Vagueira and Labrego beaches are not economically viable. However, this situation also occurs if nothing is done to preserve the natural and built heritage.

The sandy dykes have contributed to the maintenance of the coastline position mainly downdrift of the groins, although each emergency action in order to repair the dykes is further inland. Nevertheless, the retention capacity of the Vagueira groin has vanished due to a significant decrease in the supply of sediments in the littoral drift; a similar situation is present in Labrego.

Taking the present critical situation into account, the option of defending beaches is both relevant and important in order to refocus on coastal defenses and, given the current conditions, the progressive additions to the length of the groins and the reinforcement of hard defenses. Soft interventions, like sand dykes and beach nourishment, have proved effective from the point of view of protection and maintenance costs, although the challenge in obtaining deposits of sand can be a limiting factor. The investment and maintenance costs estimates should not only take into account the single market values, but also "non-market" coastal ecosystem values and should be included in the impact assessment and cost-benefit analysis (Alves et al., 2009; Roebeling et al., 2011). It should also be noted that any scenario should be based on the social importance of affected areas and costs involved, whichever option is considered in the future.

\section{References}

Alves, F.; Roebeling, P.; Pinto, P.; Batista, P. (2009) - Valuing ecosystem service losses from coastal erosion using a benefits transfer approach: a case study for the Central Portuguese coast. Journal of Coastal Research (ISSN: 0749-0258), SI56:11691173, Lisboa, Portugal. Availabe on-line at http://egeo.fcsh.unl.pt /ics2009/_docs/ICS2009_Volume_II/1169.1173_F.Alves_ICS2009.pdf

APA (2012) - Plano de acção de protecção e valorização do litoral 2012-2015. 86p., Agência Portuguesa do Ambiente, Lisboa, Portugal. Available on-line at http://www.apambiente.pt/_zdata/ destaques/2012/papvl_2012-2015-junho.pdf

Bernardes, C.; Baptista, P. (2011) - Evolução recente da barreira arenosa de Aveiro. Actas das Jornadas da Ria de Aveiro, pp.2833, Universidade de Aveiro, CESAM - Centro de Estudos do Ambiente e do Mar, Aveiro, Portugal. ISBN: 978-9727893379. Available on-line at http://la.cesam.ua.pt/documentos/LivroActas JornadasRiaAveiro2011_Cores.pdf

Boto, A.; Bernardes, C.; Dias, J.A. (1997) - Erosão litoral e recuo da linha de costa entre a Costa Nova e a praia do Areão, Portugal. In: G. Soares de Carvalho, F. Veloso Gomes \& F. Taveira Pinto (eds.), Colectânea de Ideias sobre a Zona Costeira de Portugal, pp.449-467, Associação Eurocoast - Portugal, Porto, Portugal.

Coelho, C.; Silva, R.; Veloso-Gomes, F.; Taveira-Pinto, F. (2009) Potential effects of climate change on northwest Portuguese coastal zones. ICES Journal of Marine Science 66(7):14971507. DOI: $10.1093 /$ icesjms/fsp132

Costa, C.L. (1994) - Final report of sub-project. A "wind wave climatology of the Portuguese coast". 80p., Instituto Hidrográfico/LNEC, Report 6/94-A, Lisboa, Portugal. Não publicado.

Dias, J.A.; Ferreira, Ó.; Pereira, A.R. (1994) - Estudo sintético de diagnóstico da geomorfologia e da dinâmica sedimentar dos troços costeiros entre Espinho e Nazaré. 261p., ESAMINEstudos de Ambiente e Informática / ICN - Instituto de Conservação da Natureza, Lisboa, Portugal. Available on-line at http://w3.ualg.pt/ jdias/JAD/eb_EspinhoNazare.html

Ferreira, Ó.; Garcia, T.; Matias, A.; Taborda, R.; Dias, J.A. (2006) An integrated method for the determination of set-back lines for coastal erosion hazards on sandy shores. Continental Shelf Research, 26(9):397-407. DOI: 10.1016/j.csr.2005.12.016

Gama, C.; Dias, J.A.; Ferreira, Ó.; Taborda, R. (1994) - Analysis of storm surge in Portugal, between June 1986 and May 1988. Proceedings of Littoral'94, pp.381-387, EUROCOAST. Lisboa, Portugal. Availabe on-line at http://w3.ualg.pt/ jdias/JAD/papers /CI/94_Lit94_381_CG.pdf

HM Treasury (2011) - Green Book: Appraisal and Evaluation in Central Government. 118p., HM Treasury (Her Majesty's Treasury) / TSO (The Stationery Office), London, U.K.. Available on-line at: https://www.gov.uk/government/uploads/system /uploads/attachment_data/file/220541/green_book_complete.pdf

Maia, A. (2012) - Evolução Litoral entre a Vagueira e a P. de Mira: análise geoeconómica. 94p., Dissertação de Mestrado em Ciências do Mar e das Zonas Costeiras, Universidade de Aveiro, Aveiro, Portugal. Available on-line at http://hdl.handle.net/10773 19749.

Pethick, J. (2001) - Coastal management and sea-level rise. Catena, 42(2-4):307-322. DOI: 10.1016/S0341-8162(00)00143-0

Roebeling, P.; Coelho, C.; Reis, E. (2011) - Coastal erosion and coastal defense interventions: a cost-benefit analysis. Journal of Coastal Research (ISSN: 0749-0208), SI64:1415-1419. Szczecin, Poland Availabe on-line at http://www.ics2011.pl/ artic/SP64_1415-1419_P.C.Roebeling.pdf

Roebeling, P.; Costa, L., Magalhães-Filho, L.; Tekken, V. (2013) Ecosystem service value losses from coastal erosion in Europe: historical trends and future projections. Journal Coastal Conservation, 17(3):389-395. DOI: 10.1007/s11852-013-0235-6

Santos, L. (2008). Comunicação de riscos associados às zonas costeiras - o caso da Praia da Vagueira. 298p., Dissertação de mestrado em Planeamento do Território-Riscos Naturais e Tecnológicos. Universidade de Aveiro, Aveiro, Portugal. Available on-line at http://hdl.handle.net/10773/577

Taborda, R.; Magalhães, F.; Ângelo, C. (2005) - Evaluation of coastal defence strategies in Portugal. In: B. Dean \& C. Zimmermann (eds.), Environment Friendly Coastal Protection Structures, pp.255-265, Kluwer, Netherlands. ISBN: 9781402033018.

The World Bank (s/d) - Inflation, GDP deflator (anual\%). Web page, The World Bank, Washington, DC, U.S.A. Available online at http://data.worldbank.org/indicator/NY.GDP.DEFL.KD.ZG

Zhang, K.; Douglas, B.C.; Leatherman, S.P. (2004) - Global warming and coastal erosion. Global Warming and Coastal Erosion, 64(1-2):41-58. DOI: 10.1023/B:CLIM.0000024690 .32682.48 